\title{
Impact of branding and product augmentation on decision making in the B2B market
}

\author{
N.S. Alexander and G.Bick \\ Wits Business School, University of the Witwatersrand, \\ PO Box 98, Johannesburg 2050, Republic of South Africa \\ R. Abratt* and M. Bendixen \\ Nova Southeastern University and Wits Business School, \\ 3301 College Ave, Ft Lauderdale, FI22214 \\ Abratt@huizenga nova.edu
}

Received October 2008

\begin{abstract}
The aim of this study was to investigate the impact of the brand and product augmentation on the buyers of industrial tyres. While much has been studied about branding issues in B2C markets, very little research has been conducted in B2B markets. The research method used was a conjoint analysis experiment. The subjects were decision-making unit (DMU) members of open-pit mining companies in South Africa who purchased industrial tyres for mining operations. The results suggest that the brand is very important, followed by durability, and price. Differences of magnitude amongst the members of the DMU occurred. The impact of these findings as well as the implications for buyers and suppliers are discussed.
\end{abstract}

*To whom all correspondence should be addressed.

\section{Introduction}

The branding of industrial products and services is a subject which until recently has received little attention from researchers. As industrial firms have entered hypercompetitive markets like those of consumer markets, the pressures for differentiation and sustainable competitive advantage have increased. One of the reasons for the increasingly important role of industrial branding is the commoditisation of many industrial products (Van Riel, Pahud de Mortanges \& Streukens, 2005). Branding of products is one of the avenues open to industrial marketers to create value for customers, provided that the various members of decision-making units (DMUs) perceive the product as valuable to their organisations. The purpose of this research is to identify if industrial buyers perceive branding to be an important influence in their purchasing decisions. If it is established that branding is important in B2B product procurement, then to which members of the DMU is it important?

The industry within which the concept of industrial commodity branding is to be tested is the open pit coal mining (also known as open cut or open cast mining) operations in the Mpumalanga province of South Africa. The product is tyres used on front- end loaders, which are a significant cost element in the running expenses of all mining vehicles.

While in consumer markets, tubeless tyres have been successfully branded, for example Pirelli high performance tyres, this can be attributed to the prevalence of consumer branding efforts in general, as well as the brand associations that these products have with other recognized products such as luxury and performance motor cars. However, in the open pit coal mining industry, tyres perform a functional role in an environment that is centered on maximising production capacity and keeping costs to a minimum.

A set of six tyres for a typical front-end loader costs a mine in the region of R420,000 and is replaced numerous times in the life of the vehicle. Their main markets - mining, earthmoving and construction, operate in highly contested environments with an emphasis on low cost and high volume production, making product contrasts difficult to demonstrate and placing downward pressure on price.

\section{Theoretical background and proposition development}

A review of the literature was undertaken to identify previous studies and to develop research propositions. Firstly, the relationships and roles in the buying centre are identified. Secondly, brand and brand equity in industrial markets are reviewed and lastly, the concept of the augmented product is discussed.

\section{Relationships and roles in the buying centre}

Industrial buyers are thought to be more rational and economic than consumers with determinants like product performance, product quality, delivery, service and price 
(Shipley \& Howard, 1993). However, brands could also play a significant role in this process under conditions of risk. This may occur when product failure has negative consequences for the firm or the purchaser personally (Hutton, 1997). Unlike consumer markets, organisational buying commonly involves a multitude of individuals at different levels of authority. Industrial purchasing is typically carried out by a buying centre (Theng-Lau, Goh \& Phua, 1999; Webster \& Wind, 1972) or DMU. This DMU consists of all individuals and groups participating in the purchase decision. The decision making unit (DMU) of an industrial company usually consists of the users, buyers, influencers, deciders and gatekeepers. Within this collection of individuals, personal and organisational goals combine to determine a "frame of reference" that guides each member and determines their interpretation of the behaviour of other members of the buying centre. The individual's frame of reference determines the criteria used in evaluating alternative buying actions (Webster \& Wind, 1972).

Bendixen, Bukasa and Abratt (2004) found that different members of the DMU attached different utility values to brand equity. In their research, users attached more importance to the brand than did gatekeepers. Technical specialists (influencers) were the only group to rank brand name the highest (alongside price), due to their close proximity to the functional aspects of a product as well as their understanding of risk mitigation. Bendixen, et al. (2004) also highlighted evidence that some buying centre members develop sentimental relationships for some products. This leads the authors to posit the following proposition:

Proposition 1: The importance attached to branded industrial products is dependent on an individual's role within the buying centre.

\section{Brand and brand equity in industrial markets}

A brand has been viewed as essentially being a seller's promise to deliver a specific set of features, benefits, and services consistently to the buyers (Keller, 2003; Kotler, 2000). Brands generally serve the same general purpose in B2B markets as they do in consumer markets: they facilitate the identification of products, as well as differentiate them from competition (Anderson \& Narus, 2004). Products in the B2B market often have identical physical and performance specifications, and differentiation can be hard to achieve. However, there is usually one market leader who maintains high market share, even at a premium price (Mudambi, Doyle \& Wong, 1997). The assumption would be that the brand name is the basis for this differentiation (Saunders \& Watt, 1979).

Kotler and Pfoertsch (2007) argue that branding is as relevant to B2B companies as to consumer products. A strong brand and its implicit promise of quality can provide companies with the power to command a premium price among customers and a premium stock price among investors. B2B branding and brand management will become increasingly important, and the future of brands is probably the only major sustainable competitor advantage (Kotler \& Pfoertsch 2007).
Central to the concept of differentiation is that the product attributes are not easily copied by competitors and that these different attributes are regarded as important by customers. Branded consumer products extend over an array of categories such as physical goods, services, retail outlets, people, places, organisations and ideas; and differentiation is the ingredient which sets one product apart from another and establishes the basis for branding. This differentiation is often related to the attributes and benefits of a product, but may also relate to more intangible image considerations (Keller, 2003). The stronger the association is between a brand and its practical worth in the mind of the consumer, the more likely it is that resulting attitudes will guide perceptions of the product as well as the purchase behavior of the buyer (Farquhar, 1989). The ultimate aim of branding is to establish a level of awareness and knowledge in the mind of the consumer, so as to create confidence for repeat purchases from the company and to simplify decision making (Betts, 1994; Keller, 2003). According to Webster and Keller (2004), brand managers must develop and communicate points of difference, such as technical competence or the strength of the company's reputation, as the basis for creating differentiation and providing superior customer value. Thus, in B2B marketing, a brand represents a multidimensional promise of value that includes more factors than simply the performance of the physical product (McQuiston, 2003).

While most work on brand equity has been done in consumer markets, the role and importance of brand equity in the B2B sector has also received attention in the past decades. Early studies into this subject were less conclusive on the relative impact of the brand. In one instance the use of brand names for man-made fibers was investigated and found to be confusing and ineffective (Saunders \& Watt, 1979). The researchers also suggested that branding alone, was unlikely to be of value in the market for industrial products. The findings and applications of this research are limited however, since while the products were industrial, the population sample was consumers and not commercial buyers.

A valid finding that can be applied to the broader context of industrial marketing is that the names of manufacturers and brands tend to become well known when a product fails. Sinclair and Seward (1988) took the research of Saunders and Watt (1979) further by looking at the use of branding in the reconstituted structural wood panels market of North America and Canada. They researched both manufacturers and retailers with regard to perceptions of brand equity. The results indicated that the manufacturers perceived their products to be more differentiated and branded than was considered by their customers. Retailers of wood panels identified price and availability as their most important buying considerations and less than half of them indicated that branding had increased their preference to buy. Product failure was found to cause negative perceptions of the manufacturer that could adversely affect future purchases.

In an examination of the decision factors in the mainframe computer software industry, Shaw, Giglierano and Kallis (1989) found that industrial buyers considered the following attributes as important in their preference structures: 
credibility, reliability, technical support and industry expertise. This list encompasses both tangible product aspects and well as intangible attributes and points to the existence of multiple product levels or an augmented product.

Gordon, Calantone and Di Benedetto (1993) considered brand equity in the electrical products and components market. The majority of the interviews revealed that where a brand name did exist for one of these products it was usually linked to the parent company's name. They also discovered that the brand's image was intertwined with the image of the distributor and that the choice of distributor dictated the choice of brand.

The importance of brand equity to buying centres of industrial companies has been investigated in various contexts. In an exploratory study using hypothetical industrial buying situations for office equipment, Hutton (1997) concluded that brand equity does exist in industrial markets and is evidenced by a buyer's willingness to pay a premium price for their favourite brand. Buyers were most likely to select well-known brands when the failure of the product would have negative consequences for the organisation or the buyer personally.

Michell, King and Reast (2001) investigated operating managers in industrial firms to measure the extent of their brand perceptions, and whether or not these perceptions were seen to leverage the competitive advantage of certain suppliers. Michell et al. (2001) found that brand names did indeed provide unique product identifiability and that the intangible attributes of brands were perceived to stimulate preference and loyalty when re-ordering. The variables that the respondents considered most important were quality, reliability, performance, price and availability.

Bendixen et al. (2004) considered the purchase of mediumvoltage electrical equipment and found that DMUs can be influenced by brand images that are based on non-functional and subjective attributes. Brands with the highest utility were given the highest consideration by respondents and had a relative importance of $16 \%$ of the decision making process. The most preferred brand in the survey was also able to command a price premium over lesser known brands.

In a study using Conjoint Value Analysis in the UK tractor market, Walley, Custance, Taylor, Lindgreen and Hingley (2007) found that the brand name was the most important factor when purchasing a tractor. This was more important than price, dealer proximity and the quality of dealer service. Walley et al. (2007) concluded by saying that branding plays an important role in industrial purchase decisions.

The authors therefore propose the second proposition as follows:

Proposition 2: Buyers' in B2B markets are willing to pay premium prices for well known brands that are perceived as superior to other brands.

\section{The concept of the augmented product}

The idea of the augmented product is closely linked to brand perceptions and brand equity, particularly in markets where competing firms have little tangible differentiation of their core and basic products. In a study into the Canadian pump and valve manufacturing industry, Banting (1976) reported that amongst industrial buyers the augmented service attributes of reliable delivery, prompt quotations, technical advice, discount structure and after sales service were most important.

Research conducted among manufacturers, distributors and purchasers of precision bearings was carried out by Mudambi et al. (1997), and augmented product attributes such as the willingness and ability of the supplier to respond in an emergency, technical support, training, frequency of late deliveries, distribution performance, product quality and company stability were highlighted as being important to branding in industrial markets. There is a subtle but important distinction raised by this research as well as by the work of McQuiston (2003) and Michell et al. (2001). Numerous attributes that industrial buyers consider were not only viewed as criteria on their own but also as being part of the establishment of an augmented product. This is an important finding in terms of research design. The relationship between industrial attributes is complex. In some cases buyers view attributes simply as order qualifiers, while others consider the same attributes as part of the brand building process and the 'package of total benefits' the transaction should deliver.

Mudambi (2002) found that product and service attributes in their survey reflected measures common to other organisational buying behaviour studies. The attributes of price, physical product properties, ordering procedure, delivery service, working relationship and technical support were all listed as being of importance. The third proposition therefore is:

Proposition 3: The augmented product is the primary brandbuilding variable for core products.

\section{Research methodology}

The research was conducted using a Conjoint Value Analysis experiment, which was applied after the identification of the research population, sample and tyre attributes. The attributes for the conjoint experiment were derived through a qualitative phase, which took the form of five interviews. In conjoint value analysis, the respondent is asked to make trade-off judgments, for example to decide whether one feature is desired enough to sacrifice another (Aaker, Kumar \& Day, 1995).

\section{The research population}

Decision making in an industrial context is a joint process involving an array of individuals, therefore the population for this research included the categories of role players identified in the buying centre literature and who were involved in procurement of tyres at open pit mining operations within the Mpumalanga Province of South 
Africa. This population was chosen as open pit mines are the predominant users of mining tyres. The research population consisted of three corporations, namely, Anglo Coal (a division of Anglo American Plc), Ingwe Collieries (a division of BHP Billiton Ltd) and Xstrata Coal Plc. These companies were often assisted by contract mining companies such as Moolman Mining (a division of Grinaker LTA Construction) and the vehicle rental company Barloworld Caterpillar. The total number of individuals involved in the purchase of tyres was estimated to be 84 people.

\section{Sample}

The research sample was selected on the basis of convenience for three reasons. Firstly, the mine engineers and management that were surveyed were not readily accessible. Security clearance was required to gain access to all of the mines in the research population. One of the researchers had the required security clearance to access the potential population and without this the field work would not have been possible. Secondly, the nature of the buying centre and the proposition that differing members value the attribute of brand differently supported the selection of a sample based on judgment. This conforms to Johnson and Orme (1996) who found that sufficient depth of respondents was needed to ensure reliable results using conjoint experiments. Finally, individuals were selected to ensure that all of the buying groups as identified by Webster and Wind (1972) were represented in the sample. Respondents were asked to identify their position within the buying centre. Completed questionnaires were then grouped according to three categories, namely: 10 users, 11 influencers and 9 deciders.

\section{Data collection}

Data collection took place in two phases. First, data was gathered from five qualitative interviews in order to develop the attributes for the study. Second, once the experiment had been constructed using the attributes and levels, questionnaires were distributed to the research sample $(\mathrm{n}=84)$ and collected when complete.

\section{Qualitative study methodology}

The qualitative phase was used to help define the levels for our conjoint design. The attributes and levels for use in the conjoint studies were derived through initial field interviews with industry experts and decision makers involved in the procurement, use and supply of mining tyres to open cast operations. The choice of individuals was based on judgment into the mix of people who would provide diversity of opinion on attributes and levels. The sample included users, influencers, and deciders.

The discussion document had open-ended questions designed to extract independent feedback from the respondents on their choice of important tyre procurement issues prior to prompting them with known attributes. The attributes were derived from the literature as well as one of the researcher's own industry experience. In each interview a hypothetical case of tyre purchase for a Caterpillar 992 Front End Loader was given as the context. This particular vehicle was chosen as a contextual example for discussion as it is most widely used by the population. The discussion document is shown in appendix 1 .

\section{Quantitative study methodology}

\section{Building the conjoint experiment}

Once the five exploratory interviews in the qualitative phase were completed, the data was analysed within the research context i.e. tyre purchase decisions for a Caterpillar 992 Front End Loader. From this a final list of most frequently occurring attributes and levels was selected for use in the conjoint instrument. A copy of the questionnaire is in Appendix 2. The five attributes with representative levels are presented in Table 1.

Table 1: Conjoint attributes and levels

\begin{tabular}{l|l|l|l|l}
\hline \multicolumn{1}{c|}{ Attribute } & \multicolumn{1}{c|}{ Level 1 } & \multicolumn{1}{c|}{ Level 2 } & \multicolumn{1}{c}{ Level 3 } & \multicolumn{1}{c}{ Level 4 } \\
\hline Tyre Durability (hours) & 8000 hours & 10000 hours & 12000 hours & N/A \\
\hline Price & R89, 000 & R97, 000 & R105, 000 & R111, 000 \\
\hline Brand & Bridgestone & Goodyear & Michelin & Unbranded \\
\hline Delivery Lead Time & 2 weeks & 4 weeks & 6 weeks & N/A \\
\hline Technical Support & Within 12 hours & 12 to 24 hours & 24 to 36 hours & N/A \\
\hline
\end{tabular}


The five attributes and their corresponding levels were imported from MS Excel into Sawtooth Software and 15 choice tasks were developed for the conjoint questionnaire. The final questionnaire was attached to a letter of introduction as well as the research context so as to facilitate better quality responses.

It was decided to use a traditional conjoint value analysis design with pairwise comparisons so as to simplify the research design and minimize the executive time required to complete the survey. Furthermore, as the purpose of the study was primarily to assess the relative importance of attributes and not to simulate the market, the advantages of adaptive and choice-based designs fell away. Only main effects were incorporated into the study and no interaction effects were included. The fractional factorial design used resulted in 15 comparisons which were made on a 9-point verbal rating scale to indicate preference for the profiles presented on the left and the right of the page. Regression was used to estimate the utilities of each level of each attribute for each respondent. The results were then aggregated by categories in the buying centre and in total. The relative importance of attributes was calculated from the range in utility scores by attribute compared to the total range in utility scores.

Conjoint Value Analysis encompasses a number of decompositional methods which estimate the structure of a purchaser's preferences, given their overall evaluations of a set of alternatives (Green \& Srinivasan, 1990; Curry, 1996). These alternatives are pre-specified in the form of levels within different attributes. One of the key assumptions of the methodology is that an individual's preference for an object or attribute can be decomposed into preference scores for components of an object or levels within an attribute (Cattin \& Wittink, 1982). Described another way, buyers appraise the value (utility) of a product (real or hypothetical) by combining the separate amounts of utility provided by each product attribute (Dean, 2004).

\section{Data analysis of quantitative study}

The data was processed using Sawtooth Software, to determine conjoint part-worths within each attribute and conjoint importances for the attributes relative to one another were assessed. This analysis was carried out at the individual level and consolidated to total levels.

\section{Results}

\section{Demographics}

Thirty complete questionnaires were gathered from individuals within four companies encompassing twelve different operations. All were involved in the procurement of mining tyres and their specific buying centre categorisations included 10 users, 11 influencers and 9 deciders. Twenty six of the respondents were permanently based at company offices or on mines in the Mpumalanga province of South Africa. The remaining four respondents were based in Johannesburg, Gauteng province. All the respondents participated in buying decisions for tyres on open cast mines in the Mpumalanga area. The ten users were employed at four coal mines of different companies in the area; the eleven influencers were from five different coalmining operations; and the nine decision makers came from various mines and head offices.

\section{Overall results}

The consolidated results for all respondents showed that tyre brand, durability and price had the highest relative importance at $37.55 \%, 30.27 \%$ and $13.38 \%$ respectively. The results show that branding is very important, perhaps indicating that it is associated with the credentials that stand behind the brand. Brands are associated with trustworthiness and safety. The attributes considered augmented services, namely, delivery lead time and product support scored $10.58 \%$ and $8.23 \%$ respectively. This output uses mean values and therefore masks the characteristics of specific buying groups, but it does provide a macro indication of total importance for each of the five attributes.

\section{Importance by group}

Once the data had been analyzed at an overall level it was then evaluated at the DMU level. This step determined the differing levels of importance assigned to brand and the other attributes by the decision making units. This evaluation was done by splitting the data into the categories of users; influencers; deciders, and by then calculating the mean response for each attribute.

The attribute importances for the different members of the buying centre is shown in Table 2 .

Table 2: Comparison of attribute importances percentages across the buying centre

\begin{tabular}{l|c|c|c|c|c|c}
\hline & Brand & Durability & Lead time & $\begin{array}{c}\text { Technical } \\
\text { support }\end{array}$ & Price & Total Import \\
\hline Users & 42,05 & 27,81 & 10,53 & 8,91 & 10,67 & $100 \%$ \\
\hline Influencers & 22,52 & 42,52 & 11,16 & 8,74 & 15,02 & $100 \%$ \\
\hline Deciders & 48,07 & 20,45 & 10,04 & 7,01 & 14,42 & $100 \%$ \\
\hline
\end{tabular}

Sample size: 10 users; 11 influencers; 9 deciders 
Users ascribed the highest importance to brand (42.05), followed by tyre durability (27.81) relative to the other three elements. The attributes of price (10.67), lead time (10.53) and technical support (8.91) were almost equal in magnitude but considerably less than the two primary attributes of brand and tyre durability.

People who influenced the purchase attributed the highest importance to tyre durability (42.52) followed by brand (22.52) and price. Price was again of lower importance than expected given the commodity status of the product. Lead time (11.16) and technical support (8.74) were considered least important.

Deciders had a similar pattern of importance for the attributes to that of Users but differed notably on the attribute of tyre durability (20.45) from that of the Influencers (42.52). In considering the primary outcomes of the data analysis, the weight of brand over the other four attributes featured prominently. The augmented product attributes scored low in relation to the other three attributes in all instances. When investigating the values given by each group, differences in inclination were detected between the three groups in the buying centre.

\section{Utility of branded over unbranded tyres}

Analysis of the levels within the branded / unbranded conjoint attribute determined the utility ascribed to brand by the different groups in contrast to the support for unbranded tyres. The results depicted in table 3 show support for the three brands combined, namely Michelin, Bridgestone and Goodyear, over the choice of an unbranded tyre. Although buyers may be aware of the source of these unbranded tyres, they do not know what the quality and reliability levels are. Table 3 shows the comparison of Brand part-worth utilities across the buying centre.

Table 3: Comparison of brand part-worth utilities across the buying centre

\begin{tabular}{l|c|c|c|c|c}
\hline & & & & & \\
& Michelin & Bridgestone & Goodyear & Total branded & Unbranded \\
\hline Users & $+32,979$ & $+62,065$ & $-7,146$ & $+87,897$ & $-87,897$ \\
\hline Influencers & $-14,452$ & $+26,912$ & $+19,609$ & $+32,068$ & $-32,068$ \\
\hline Deciders & $+67,880$ & $+35,798$ & $+50,364$ & $+154,042$ & $-154,042$ \\
\hline
\end{tabular}

Users demonstrated the second highest appreciation for branded over unbranded tyres. A lower part-worth was apportioned to brand by Influencers represented by a $+32,068$ point advantage over the unbranded goods. Deciders offered the highest importance for branded tyres. The higher utility for branded over unbranded tyres featured prominently in the results and different buying centres attached a different weight to this decision.

\section{Price premium for branded tyres}

The established brands of Bridgestone, Michelin and Goodyear had overall positive utilities of $+41,591,+28,802$ and $+20,942$ respectively as depicted in Table 4, while the unbranded tyre had a negative utility of $-91,336$. Price utility ranged from $+28,639$ for the cheapest option of tyre to 37,238 for the most expensive option.

Details of the scores by buying group are shown in Table 4 .

It was established that each buying centre as well as the group overall were prepared to pay a price premium for brand. It confirms that the buying centre is prepared to pay more for well known brands. By using linear interpolation, a price of R103,011 was determined to have zero utility. The mean of the three brands produced a utility of $+30,45$. Again using linear interpolation and all other things being equal, a utility of $+30,45$ represented a price of R109,404, which is a premium of R6,393 above the zero utility price. Due to the very strong utilities for brand, certain calculations fell outside the upper and lower price limits of the survey. Where this occurred, prices were adjusted to the maximum or minimum, according to what was required. Considering the foregoing explanation and with the "brand-price" dyad set at zero, a mean of the branded tyres returned a result which could command a price premium of $6,2 \%$ relative to an "average" price of R103,011 as depicted in Figure 1.

Using similar logic, the unbranded tyre with utility of 91,336 would have to discount its price by R14,011 or $13,6 \%$ to the "average" price. Thus in this study, the branded items could collectively afford a price premium of $19,80 \%$ over unbranded tyres in the market.

Among all three buying groups, branded products were preferred to unbranded and Deciders gave the strongest support for brand with utility of $+154,04$. The three DMUs all supported a premium price for branded goods. It was established that the mean premium price for the entyre sample was $6,2 \%$ higher than the "neutral' price and that suppliers of unbranded products would have to discount their tyres by $13,6 \%$ to achieve the neutral utility price. These calculations were achieved using linear interpolation and the overall price premium that a branded tyre commanded over unbranded tyres was $19,8 \%$. 
Table 4: Brand utilities and price premiums by buying group

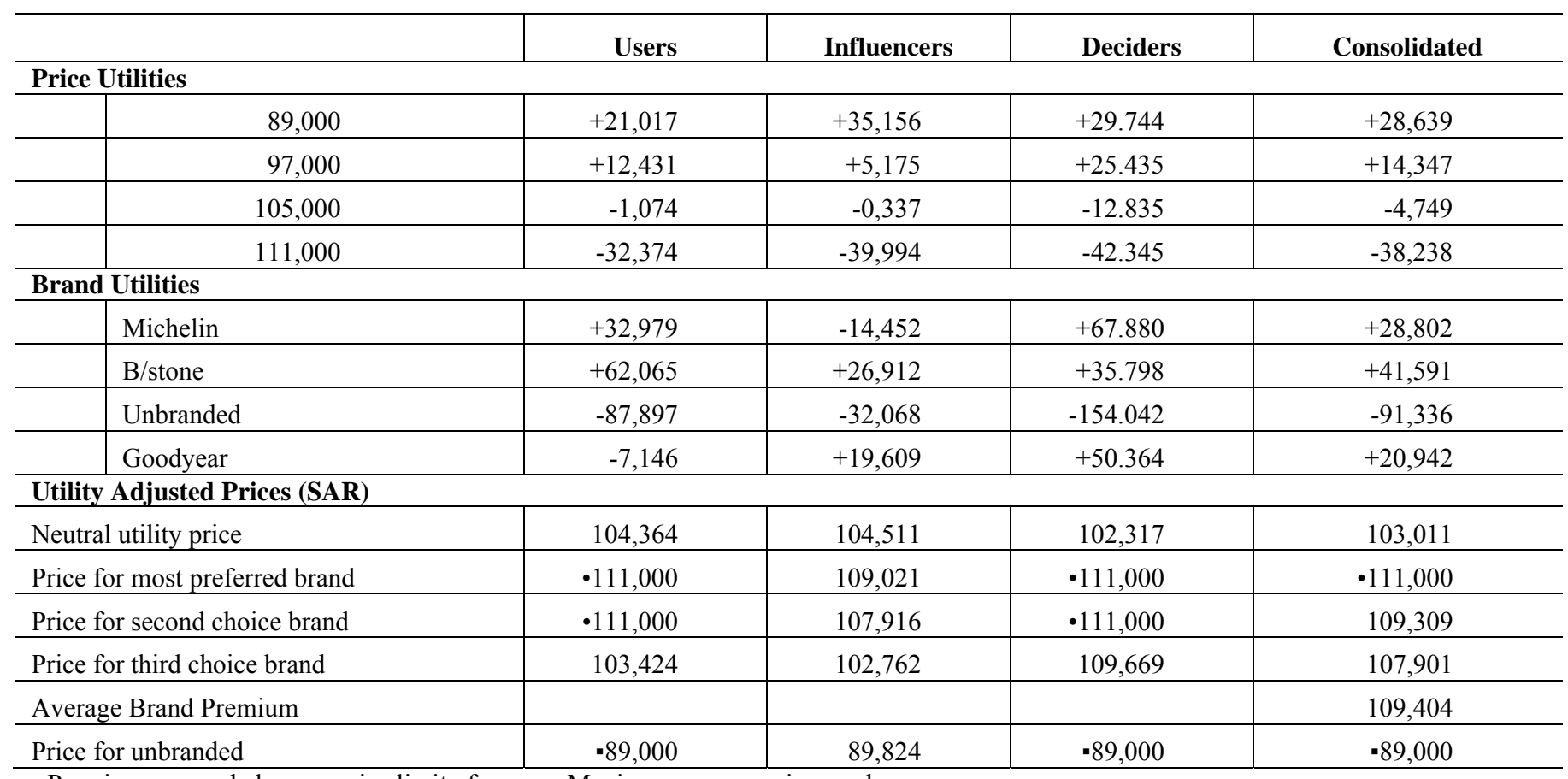

- Premiums exceeded upper price limit of survey. Maximum survey price used

- Prices exceeded lower price limit of survey. Minimum survey price used

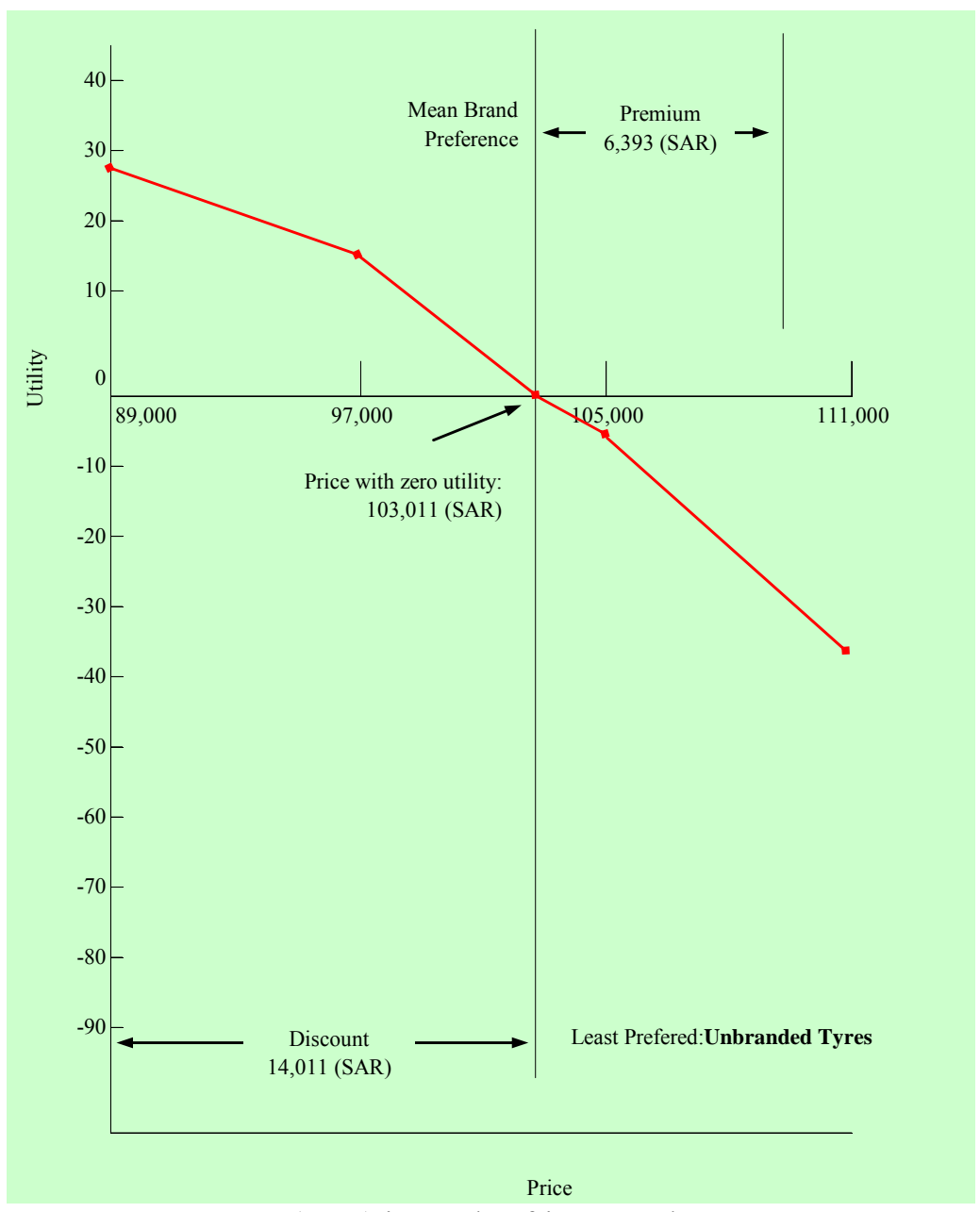

(SAR) is South African Rand.

$\$ 1=$ R7 approximately at the time of the study.

Figure 1: Consolidated brand-price dyad 


\section{Discussion}

\section{Importance of the brand}

Bendixen et al. (2004) determined that individuals within different buying centre roles placed different weighting on the importance of brand. However, their survey also found that brand did not feature as the most important element, except amongst technical individuals who rated the attribute alongside price. It was expected that a similar pattern would be found amongst purchasers of mining tyres and specifically that the Users of the tyres would rate brand highest.

Lau, Goh and Phua (1999) suggested that the different buying centres within the same organisation may have different internal structures. Their rationale was that buying centres derive their structure from the regularized patterning of interpersonal communication and not from the structural configuration of the formal organisation. This provides a partial explanation for the differences in the research. The buying structures of open pit mining companies in Southern Africa is complex and involves both the decision making members on the mine itself as well as individuals within head office and regional offices who assist the buying process with commercial and legal expertise. Large costly purchases including the acquisition of tyres start with commercial assessment from a dedicated division within the mining group and once preliminary approval has been obtained the feasibility and suitability of the supplier and its products is assessed by engineers and management on the mine itself.

The consolidated results for the three buying groups indicated support for the brand attribute across the buying centre and not just within certain groups.

Users considered brand to be most important to them and this may be attributed to their close proximity to the functional elements of tyre operation. The importance score they gave to the element was $42,06 \%$, which was $14,24 \%$ higher than the score for their second place attribute of durability. The fitting and maintenance of tyres onto heavy machinery and the consequences of product failure, which can easily result in death or considerable financial loss, are a routine part of the User's job. As a consequence blame may be apportioned to the users in the case of an accident if it were found that they had been negligent in their procurement or use of the product. Users are also the focal point of contact for the mine with tyre salespeople and technical specialists.

Influencers did not rate brand as their highest priority but durability with $42,53 \%$ importance. The brand variable was second with $22,53 \%$, a difference of $20 \%$. Individuals within this buying centre were found to hold commercial, buying and support positions to the purchase decisions and were usually separated geographically and practically from the daily use and purchase of industrial tyres. This may explain why they valued tyre durability more highly than brand and more highly than the other two decision groups, since they view the purchase at a predominantly commercial level and are detached from the influence of tyre salespeople and the imperatives of safety.

Deciders gave their highest importance score to brand at $48,07 \%$. Durability and price were $27,62 \%$ less and $33,65 \%$ less respectively. This group also provided the highest score for branded tyre advantage over unbranded products. Deciders have the highest degree of authority in tyre purchase decisions. This group included financial directors, commercial specialists, health \& safety managers and operations managers. Since poor tyre performance adversely affects mining production, can jeopardize the safety of vehicle operators, and cause damage to machinery, ultimate responsibility will rest with the buyers who had the most authority. As per the brand names of the tyres featured, it may indicate that there is an association of trust and safety attached to these branded goods in this potentially dangerous environment. This is supported by brand theory which states that differentiation of a product relates to more intangible image considerations (Keller, 2003).

The varying degree of importance attached by different buyers was confirmed in Hayes and Hartley (1989) who indicated that industrial sales people vary and adjust their selling behavior depending on the buyer's role in the organisation. For Users, the findings concur with prior research results in that they have a close proximity to the product and therefore value the brand attribute because of the protection it may provide in avoiding costly or dangerous failures (Rangan \& Bowman, 1992; Matthyssens \& Vandenbempt, 1998; Bendixen et al., 2004). Influencers on the other hand fall into the category of what Mudambi (2002) identified as "high product tangibility", whereby they place a higher importance on the commercial aspects of procurement such as product longevity, reliability and price and give less attention to branding. This also supports the research of Bendixen et al. (2004). Deciders, like Users, may be categorized, using Mudambi (2002), as "brand sensitive". This may be attributable to similar reasons as those identified with Users, but was not expected from the research. Deciders on mining operations do comprehend the negative impact that time delays and product failure can have on production rates and safety issues, but it was initially expected that they would rate durability and price more highly. However, there has been growing emphasis placed on health \& safety amongst industrial companies, and mine management go so far as to terminate relationships with suppliers or contractors who transgress safety requirements or who are seen as potential risks (Coetzee, 2005). This may help to explain the high value attached to brand for Deciders. The brand name of tyres may be serving as a proxy for safety and trust issues based on the track record of supply and performance.

The branded tyres used in this study were Michelin, Bridgestone and Goodyear, all well known consumer brands with high brand equity. They have had well known communication campaigns and have used a variety of promotional tools aimed at the consumer market. Most members of an industrial DMU are also consumers. 


\section{Buyers willingness to pay premium prices}

Open cast mining operations are by nature focused on high volume and low cost production, and therefore, it was expected that the brand of tyre would be relatively unimportant or secondary to price and durability. However, the research revealed that all three of the buying centre groups rated brand as either first or second in priority, elevating the value of the product beyond its functional purpose (Farquhar, 1989). Across all three groups brand was rated as more important than price. This is perhaps a result of the brands associations with trustworthiness and safety. Relative to brand and durability, price featured lower with an importance level of $13,38 \%$ overall. This outcome was not expected from the research, since there is little tangible difference between tyres of different makes, which are used on the sample vehicle of the survey, and since customers typically purchase commodities on price, it was expected that all mine personnel would rate price or durability of greater consequence (Dolak, 2005). However, there was clear evidence that at a consolidated level and at the decision making units, industrial buyers were prepared to pay a premium price for their preferred brand. One can therefore conclude that tyres are a product with high brand equity and can obtain a price premium in the B2B market. This is shown in Figure 2.

It has been found that where brand equity exists, in the form of perceived quality and name awareness, sellers of industrial commodity goods can command a premium price (Hutton, 1997). Aaker (1991) also identified name awareness as one of the value enhancing elements of brand equity that accrues to the supplying company. McQuiston (2003) discovered that Finnish sheet steel manufacturer Rautaruukki was able to charge a premium price on its RAEX LASER Steel product by increasing its brand equity and name awareness, which it did by improving product logistics, customer support and corporate image.

\section{Role of the augmented product}

The concept of the augmented product was expected to feature prominently in the research as it was identified as a key driver of brand equity in the literature review. However, delivery lead time and product support were given the lowest scores in all instances and at the consolidated level.

The positions did not change at the individual buying group level, only the importance scores varied. This may be attributed to a number of different causes that have been explored at a qualitative level within the research sample.

- First, it must be remembered that these scores are relative to the other three attributes and therefore they are not necessarily unimportant but should rather have been viewed as less important than brand, durability and price.

- $\quad$ Second, provided mine management maintains its haul roads and loading areas in good condition, tyres can be used for thousands of operating hours before needing replacement or technical support. One of the primary causes of premature tyre failure is rock cuts and mine maintenance has ongoing projects to minimise this by grading roads and cleaning up around loading and dump sites.

- Third, the suitability of tyres is determined by collaboration between tyre manufacturers, vehicle manufacturers and mine engineers. The suitability of tyre models is based on issues such as loading weight, hauling distance, ambient temperature and vehicle configuration and once established does not often change. As a result of this, technical support is only required when the operating variables change or when consistent problems are encountered with a particular tyre model.

- $\quad$ Fourth, increasing amounts of procurement are being negotiated at corporate level where global supply agreements may be made. For example, Michelin and BHP Billiton have a global supply agreement on tyres for mines in South Africa, Australia and South America. Delivery lead times are often part of this process and are therefore beyond the control of local buying groups.

- Fifth, on all of the mines at which surveys were conducted, the day to day maintenance of tyres, for example, inflation pressure checks, tyre mounting and demounting, were all carried out by third parties or the mine workshop personnel. Tyre manufacturers supplied the product and expertise, but the regular support was provided by another organisation. Many of the regular support issues and trouble shooting are addressed by these intermediaries, which shield the manufacturers to some degree.

The low scores depicted in Table 2 were not supported by previous studies and were not anticipated. The work of McQuiston (2003), which was with a pure industrial commodity, namely sheet steel, found that branding was not simply the recognition of a name, but rather a multidimensional construct. Rautaruukki steel gained market advantage, customer loyalty and premium prices by providing its market with three product enhancing attributes: supply logistics, customer support and corporate image. Tyre delivery lead time and product support were expected to add to the branding purchase experience. In the light of McQuiston's (2003) research, one reason for the low scores may be that respondents already considered such attributes as inclusive with the brand attribute.

In earlier research, Mudambi et al. (1997) developed a conceptual model for industrial branding which consisted of four components: product performance, distribution (ordering and delivery) performance, support service performance and company performance. The product performance element of their model parallels the tyre durability attribute of the research. The distribution and support service elements match the outcomes of the research qualitative phase from which lead time and technical support were derived. 


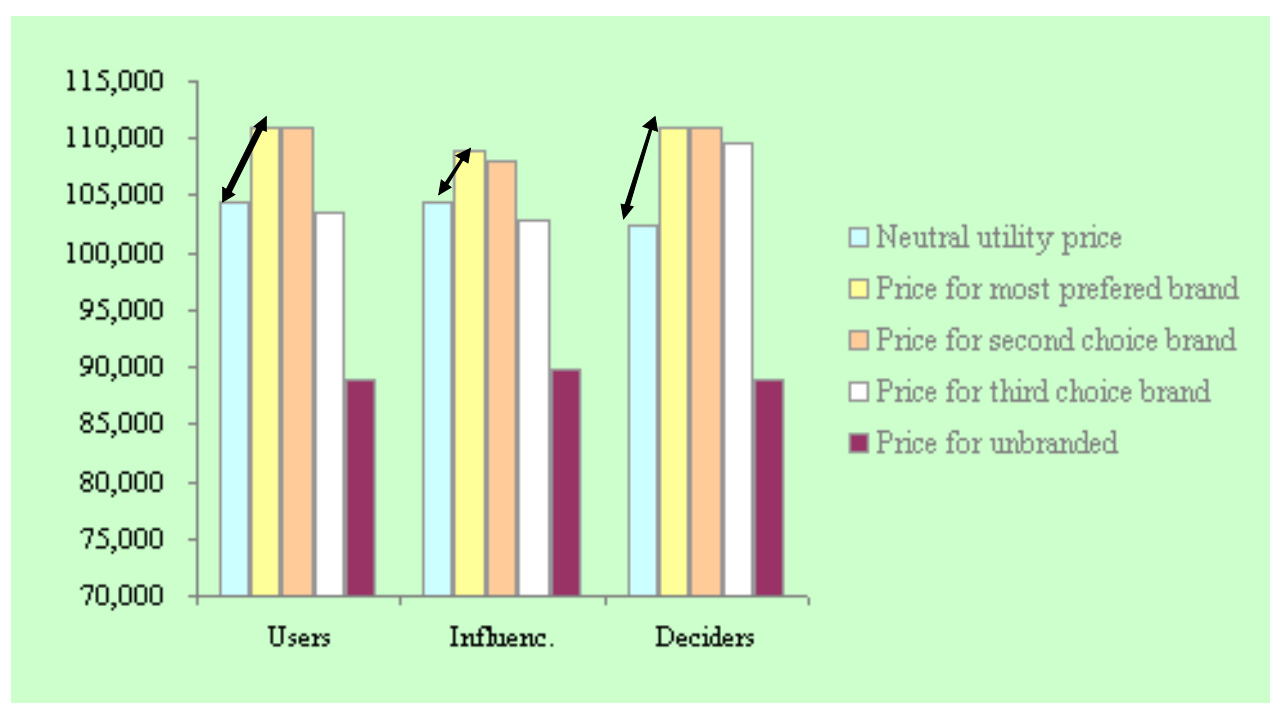

$\begin{array}{ll} & \text { Users } \\ \text { Neutral utility price } & 104,364 \\ \text { Price for most preferred brand } & 111,000 \\ \text { Price for second choice brand } & 111,000 \\ \text { Price for third choice brand } & 103,424 \\ \text { Price for unbranded } & 89,000\end{array}$

Figure 2: Price premiums by buying group

\section{Conclusions}

\section{The importance of brand}

The results of the conjoint experiment provide clear evidence that different buying groups attached different levels of importance to branding. Users, Influencers and Deciders as shown in table 2 scored the attribute at $42,05 \%$, $22,52 \%$ and $48,07 \%$ respectively. The same groups differed from the mean by $4,5 \%,-15,03 \%$ and $10,52 \%$ respectively. This leads to support of proposition 1, which stated: The importance attached to branded products is dependent on an individual's position within the buying centre.

\section{Buyers' willingness to pay premium prices}

The willingness of the buyers to pay price premiums appears to be driven by name awareness and the risk mitigation associated with well known brands because of the high consequences of tyre failure. This is further borne out by the low scores for the augmented product attributes of lead time and product support. Augmented product offerings featured prominently in other studies of brand equity (Mudambi et al., 1997; McQuiston, 2003). The fact that the physical tyre products have very little that differentiates them from one another adds to the argument that tyre products must be considered commodities, at least at the tangible product level, and that the premium price is derived from name awareness and an association with trustworthiness and reliability. These results lead to support for proposition 2, which stated: Buyers' in B2B markets are willing to pay premium prices for well known brands that are perceived as superior to other brands.

$\begin{array}{rr}\text { Influenc. } & \text { Deciders } \\ 104,511 & 102,317 \\ 109,021 & 111,000 \\ 107,916 & 111,000 \\ 102,762 & 109,660 \\ 89,824 & 89,000\end{array}$

\section{The importance of augmented product attributes}

The low importance scores for delivery lead time and product support in table 2 were not expected. These attributes had been central to the building of brand equity in other industrial branding situations and they had been identified as important factors in the qualitative phase. Reasons for the low scores relative to the other three attributes were explored and should have implications for the design of similar research for the mining tyres industry in the future. These outcomes lead to a lack of support for proposition 3, which stated: The augmented product was the primary brand-equity-generating variable for core products.

\section{Recommendations}

\section{Buyers}

Mining companies may be paying premium prices for tyres in order to satisfy safety and reliability concerns. There is no question that management should go out of its way to ensure the safety of its staff, contractors and vehicles, but if closer analysis was given to tyre performance and maintenance, they may be able to erode the price premium and still derive the benefits.

By ascribing such high importance to brand, the mines are not only paying a price premium, but they are also diverting attention away from the critical attribute of tyre durability. If decision makers blindly accept brands, there is a danger that they will overlook poor performance or manufacturing faults. Brands are however very important, as they stand for a certain level of quality and are associated with intangible 
image elements. The critical cost component with tyres is that they be managed very closely to ensure that maximum operating hours are achieved. Research amongst the same sample of respondents indicated that tyres are currently only achieving $40-60 \%$ of their intended operating hours (Gavriil, 2006; Grobler, 2006).

\section{Suppliers}

Suppliers of mining tyres could find confirmation in this research that they are able to command premium prices over unknown or unbranded tyres due to the imperatives of mine safety and tyre reliability. Certain brands also commanded a higher price premium over other known brands.

There is potential for suppliers of mining tyres to be complacent given their market dominance. The three manufacturers used in this research were Goodyear, Bridgestone and Michelin. These three companies have been the dominant manufacturers of ultra large earthmover tyres for decades. The price premiums they command will not be eroded easily, but the imperative from mines to keep operating costs low and production rates high will encourage the entrance of lower cost producers and perhaps substitutes such as mining tyre retreaders.

\section{Limitations and recommendations for further research}

\section{Limitations}

In addition to the attributes researched, mine operations also purchase tyres based on historical relationships. Global supply agreements were also identified and often negotiated at a very senior level and at times in another country. This could result in a mine's engineering team having to accept one particular brand of tyre on their mine when they actually would prefer another. The manner in which the choice tasks were posed in the conjoint experiment should have eliminated this bias, but there is no way of determining the extent of influence such fixed arrangements had on the outcomes without conducting further research.

The mining environment is also a unique industrial situation. Items such as vehicles and tyres are simply a means to an end. In general discussions with mine staff there was clear evidence of contention between maintenance and production staff. Where maintenance staff were responsible for budgeted expenses such as tyres, they expressed interest in cost cutting initiatives. Production engineers however, are primarily incentivised on volume levels and definitely see tyres as a means of getting the job done. Consequently they would be less concerned with price and more interested in keeping vehicles operational. Any future research in this field should pay closer attention to the vested interest of the survey sample.

\section{Recommendations for further research}

Indication was given by the respondents in both the qualitative phase and the research that safety issues and production reliability were an essential part of brand value. Scope exists for research into this to determine the relative importance of such attributes in comparison to the traditional attributes identified in the literature. An anticipated limitation however, would be how to qualify the safety factor, since choice levels of 'safe' and 'unsafe' would be inadequate. Value could be derived by replicating this research with a larger sample size. A specific requirement of this would be that a statistically reliable sample be obtained in each buying center group. This research could be replicated in other open cast mining industries such as iron ore and diamonds as well as in other similar environments such as the coal fields of New South Wales, Australia. There is scope to measure the different preferences for branded tyres between mining companies. There were indications that mine personnel are influenced to purchase certain brands based on inducements from suppliers. Since this type of behavior is prohibited by the organisations it would be difficult to measure, but it is an externality that would ultimately lead to higher prices and other market inefficiencies.

Research could be conducted on a similar basis into other mining commodities, for example, steel tubing, cabling, hand tools, welding consumables and fasteners.

\section{References}

Aaker, D.A. 1991. Managing brand equity: Capitalizing on the value of a brand name. New York: The Free Press.

Aaker, D.A., Kumar, V. \& Day, G.S. 1995. Marketing research. New York: Wiley.

Anderson, J.C. \& Narus, J.A. 2004. Business market management: Understanding, creating, and delivering value. Englewood Cliffs, New Jersey: Pearson PrenticeHall.

Banting, P.M. 1976. 'Customer service in industrial marketing: A comparative study', European Journal of Marketing, 10(3): 136-145.

Bendixen, M., Bukasa, K.A. \& Abratt, R. 2004. 'Brand equity in the business-to-business market', Industrial Marketing Management, 33: 371-380.

Betts, P. 1994. 'Brand development: Commodity markets and manufacturer-retailer relationships', Marketing Intelligence \& Planning, 12(9): 18-23.

Cattin, P. \& Wittink, D.R. 1982. 'Commercial use of conjoint analysis: A survey, Journal of Marketing, 46:44-53.

Coetzee, S. 2005. Buyer, Hexagon Business Solutions / BHP Billiton Ltd, personal communication, 29 August.

Curry, J. 1996. 'Understanding conjoint analysis in 15 minutes', [online] URL:http://www.sawtoothsoftware.com.technicaldownloads .shtml\#fifmin. Accessed 6 January 2005.

Dean, D.H. 2004. 'Evaluating potential brand associations through conjoint analysis and market simulation', Journal of Product and Brand Management, 13: 506-513 
Dolak, D. 2005. 'How to brand and market a commodity'. [online]

URL:http://www.brandchannel.com/papers_review.asp?sp_i $\mathrm{d}=570$. Accessed 6 June 2005.

Farquhar, P.H. 1989. 'Managing brand equity', Marketing Research: A Magazine of Management and Applications, 1(3): 24-33.

Gavriil, G. 2006. Commodity manager for Anglo Coal, personal communication, 1 June.

Gordon, G.L., Calantone, R.J. \& Di Benedetto, C.A. 1993. 'Brand equity in the business-to-business sector: An exploratory study', Journal of Product \& Brand Management, 2(3): 4-16.

Green, P.E. \& Srinivasan, V. 1990. 'Conjoint analysis in marketing: New developments with implications for research and practice', Journal of Marketing, October: 319.

Grobler; A. 2006. Commodity Manager for Hexagon Business Solutions / BHP Billiton Ltd, personal communication, 9 June.

Hayes, H.M. \& Hartley, S.W. 1989. 'How buyers view industrial salespeople', Industrial Marketing Management, 18: $73-80$.

Hutton, J.G. 1997. 'A study of brand equity in an organisational-buying context', Journal of Product \& Brand Management, 6(6): 428-439.

Johnson, R.M. \& Orme, B.K. 1996. 'How many questions should you ask in choice-based conjoint studies?' [online]URL:http://www.sawtoothsoftware.com/technicaldo wnloads.shtml\#howmany. Accessed 6 January 2005.

Keller, K.L. 2003. Strategic brand management. $11^{\text {th }}$ Edition. Upper Saddle River: Pearson Education Inc.

Kotler, P. 2000. Marketing management: The millennium edition. Upper Saddle River, NJ: Prentice-Hall.

Kotler, P. \& Pfoertsch, W. 2007. 'Being known or being one of many: The need for brand management for business-tobusiness (B2B) companies', Journal of Business and Industrial Marketing, 22(6): 357-362.

Lau, G-T., Goh, M. \& Phua, S.L. 1999. 'Purchase related factors and buying centre structure: An empirical assessment', Industrial Marketing Management, 28: 573589.

Matthyssens, P. \& Vandenbempt, K. 1998. 'Creating competitive advantage in industrial services', Journal of Business \& Industrial Marketing, 13(4/5): 339-355.

McQuiston, D.H. 2003. 'Successful branding of a commodity product: The case of RAEX LASER Steel', Industrial Marketing Management, 33: 345-354.
Michell, P., King, J. \& Reast, J. 2001. 'Brand values related to industrial products', Industrial Marketing Management, 30: $415-425$.

Mudambi, S.M., Doyle, P. \& Wong, V. 1997. 'An exploration of branding in industrial markets', Industrial Marketing Management, 16: 433-446.

Mudambi, S. 2002. 'Branding importance in business-tobusiness markets: Three buyer clusters', Industrial Marketing Management, 31: 525-533.

Rangan, V.K. \& Bowman, G.T. 1992. 'Beating the commodity magnet', Industrial Marketing Management, 21:215-224.

Saunders, J.A. \& Watt, F.A.W. 1979.'Do brand names differentiate identical industrial products?' Industrial Marketing Management, 8: 114-123.

Shaw, J., Giglierano, J. \& Kallis, J. 1989. 'Marketing complex technical products: The importance of intangible attributes', Industrial Marketing Management, 18: 45-53.

Shipley, D. \& Howard, P. 1993. 'Brand-naming industrial products', Industrial Marketing Management, 22: 59-66.

Sinclair, S.A. \& Seward, K.E. 1988. 'Effectiveness of branding a commodity product', Industrial Marketing Management, 17: 23-33.

Theng Lau, G., Goh, M. \& Phua, S.L. 1999. 'Purchase related factors and buying center structure', Industrial Marketing Management, 28: 573-587.

Van Riel, A. C. R., Pahud de Mortanges, C. \& Streukens, S. 2005. 'Marketing antecedents of industrial brand equity: An empirical investigation in speciality chemicals', Industrial Marketing Management, 34: 841-847.

Walley, K., Custance, P., Taylor, S., Lindgreen, A. \& Hingley, M. 2007. 'The importance of brand in the industrial purchase decision: A case study of the UK tractor market', Journal of Business and Industrial Marketing, 22: 383-393.

Webster, F.E. \& Keller, K.L. 2004. 'A roadmap for branding in industrial markets', Brand Management,11: 388-402.

Webster, F.E. jr. \& Wind, Y. 1972. Organisational buying behavior. Englewood Cliffs, New Jersey: Prentice-Hall. 


\section{Appendix 1: Pilot Study Master}

Name of Respondent

Company

Title

1. Explanation of Context.

2. Deriving the attributes.

2.1. What do you consider the purchase criteria to be when your mining company is procuring tyres?

\begin{tabular}{|l|l|l|}
\hline & \\
\hline & & \\
\hline & & \\
\hline & & \\
\hline
\end{tabular}

2.2. In addition to these items you have provided would you consider any of the following to also be of importance? (Interviewer to prompt interviewee on items not mentioned in 2.1)

\begin{tabular}{|l|l|l|}
\hline Durability (hours) & Brand & Association (e.g. CAT) \\
\hline Resistance to cutting & Type Technology & Speed Rating \\
\hline Traction & Tech. Expertise of seller & Load carrying capacity \\
\hline Price & Delivery time & Safety \\
\hline
\end{tabular}

2.3. Your complete list of attributes is as follows?

\begin{tabular}{|l|l|l|}
\hline & & \\
\hline & & \\
\hline & & \\
\hline & & \\
\hline
\end{tabular}

Do you agree?

Interviewer to add any additional items identified by the respondent.

2.4 Rank ordering the attributes. Please identify the 7 most important attributes from the complete list.

\begin{tabular}{|l|l|l|}
\hline 1 & 4 & 6 \\
\hline 2 & 5 & 7 \\
\hline 3 & \multicolumn{2}{|l}{} \\
\cline { 1 - 2 } & &
\end{tabular}


3. Deriving the levels for each attribute

3.1. You have provided me with a list of attributes you consider most important. The next step requires the establishment of levels within each of these attributes. For example, if you consider delivery period to be important, what are the three typical periods within which types are delivered; one day; three days; one week?

\begin{tabular}{|c|c|c|c|c|}
\hline Attribute & Level 1 & Level 2 & Level 3 & Level 4 \\
\hline & & & & \\
\hline & & & & \\
\hline & & & & \\
\hline & & & & \\
\hline & & & & \\
\hline & & & & \\
\hline
\end{tabular}

4. Criteria for brand importance

4.1. Definition of brand and brand equity and the concept of the augmented product

4.2. When considering the concept of an industrial brand and how it applies to mining tyres, what do you consider to be the elements that contribute to building the brand and brand equity?

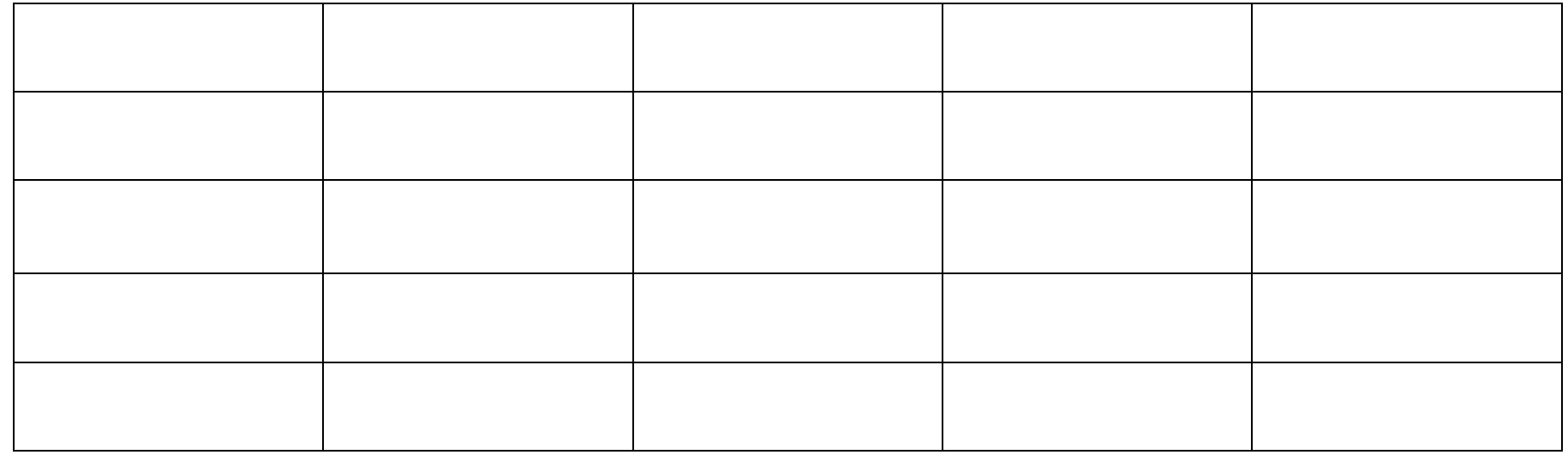

5. Explanation of how the data will be used.

6. Wrap-up and thank you.

Interview conducted by:

Date of Interview 


\section{Appendix 2: final conjoint questionnaire}

Your Professional Details

Contact Telephone No.

Area Code ( )

Number (

)

Title / Position

Please indicate your role in tyre purchase decisions by ticking the box next to the title and narrative that best describes your function.

\begin{tabular}{|l|l|l|}
\hline Initiator & $\begin{array}{l}\text { You are responsible for managing company tyre inventories and initiate } \\
\text { purchase and procurement decisions. }\end{array}$ \\
\hline User & $\begin{array}{l}\text { You are involved in the fitting, monitoring and use of OTR (Off-the-Road) } \\
\text { tyres. }\end{array}$ \\
\hline & Influencer & You influence tyre purchase through your expertise and / or experience. \\
\hline Buyer & $\begin{array}{l}\text { You fulfill a formal function as buyer for an organisation and are involved in } \\
\text { the commercial decisions involved in pricing and vendor selection criteria. }\end{array}$ \\
\hline Approver & $\begin{array}{l}\text { You have the final say or a significant role in tyre purchases because of the } \\
\text { high cost and potential impact on vehicle production. }\end{array}$ \\
\hline Gate Keeper & $\begin{array}{l}\text { You are required to approve the use of certain tyres and vendors based on the } \\
\text { standards and operating procedures of your company. }\end{array}$ \\
\hline & $\begin{array}{l}\text { You influence tyre purchase decisions by ensuring security clearance, } \\
\text { compliance, matters pertaining to health and safety and contractor induction. }\end{array}$ \\
\hline
\end{tabular}

1. When buying tyres, which of the following proposals would prefer?

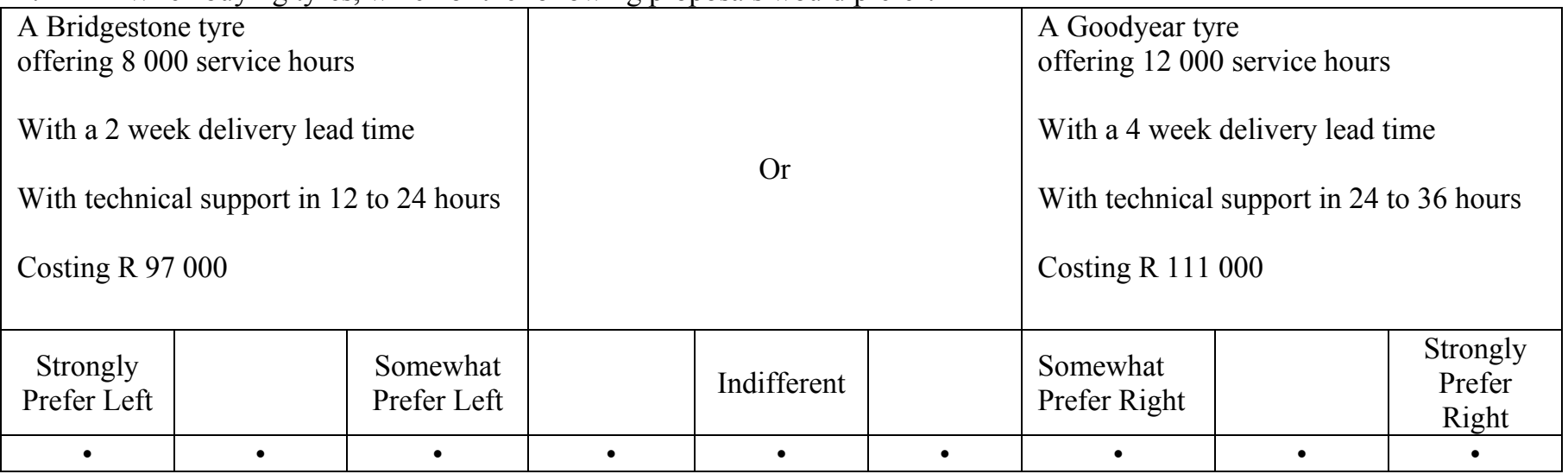

Place a cross over the dot that best represents your preference.

2. When buying tyres, which of the following proposals would you prefer?

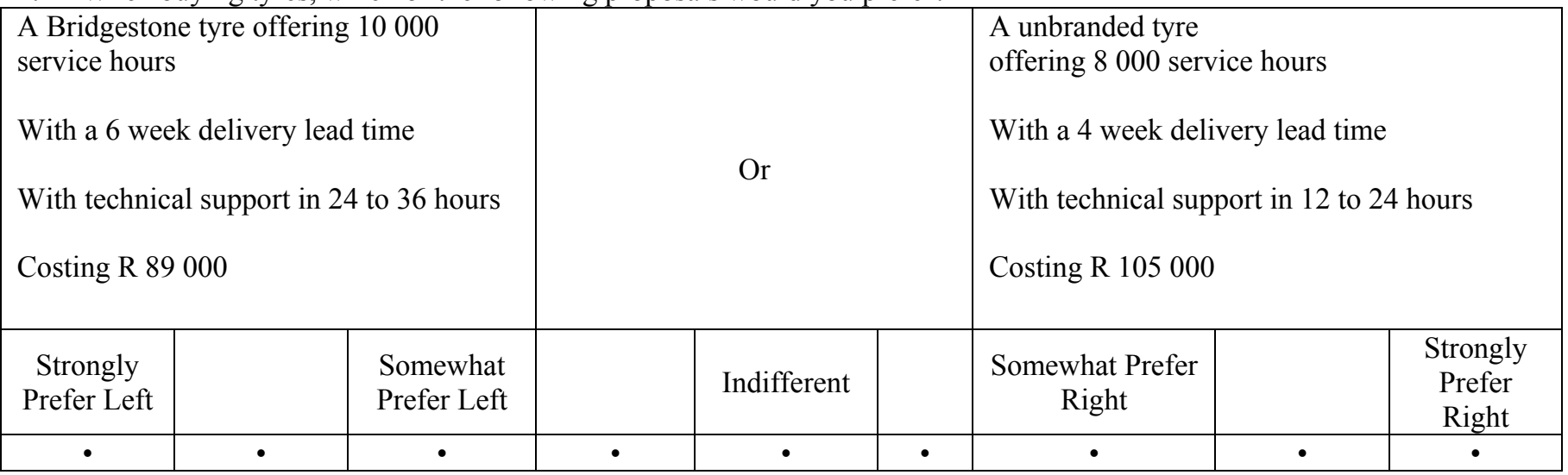

Place a cross over the dot that best represents your preference. 
3. When buying tyres, which of the following proposals would you prefer?

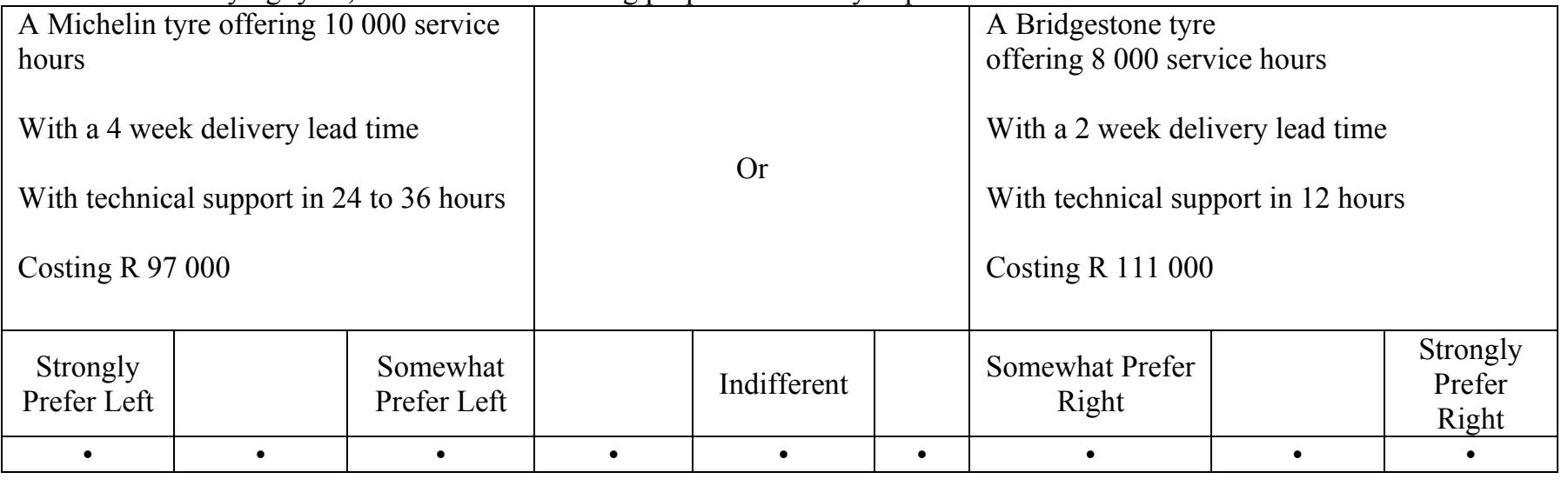

Place a cross over the dot that best represents your preference.

4. When buying tyres, which of the following proposals would you prefer?

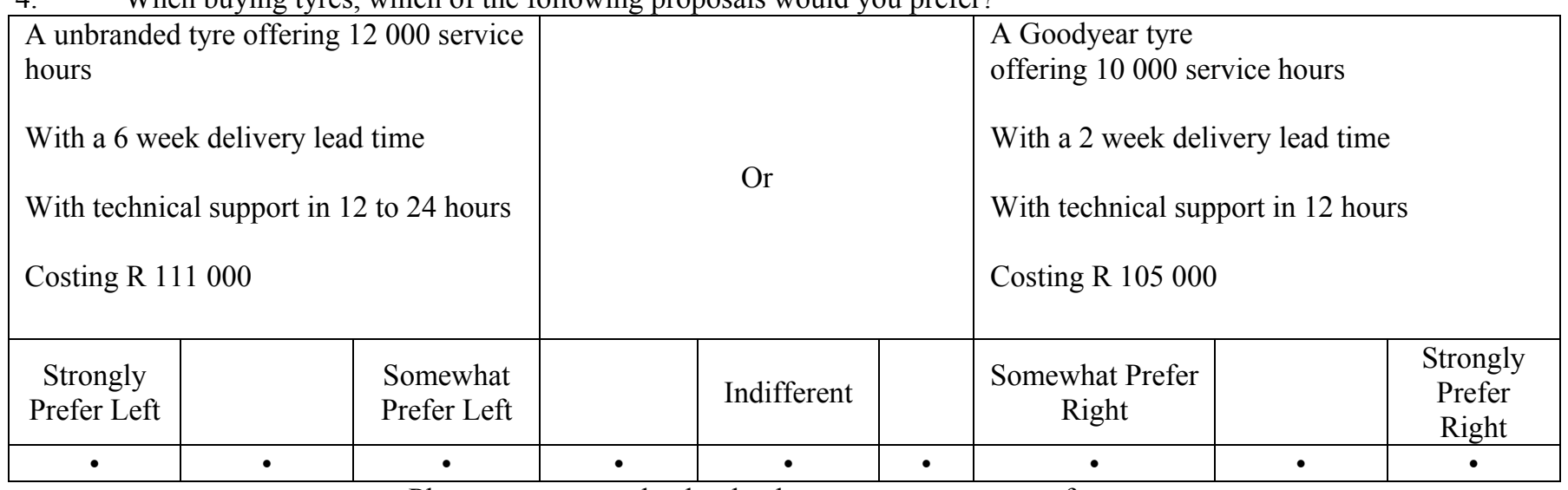

Place a cross over the dot that best represents your preference.

5. When buying tyres, which of the following proposals would you prefer?

\begin{tabular}{|l|l|l|l|l|l|l|}
\hline $\begin{array}{l}\text { A Goodyear tyre offering } 10000 \text { service } \\
\text { hours }\end{array}$ & \multicolumn{3}{|c|}{ Or } \\
With a 6 week delivery lead time \\
With technical support in 12 to 24 hours \\
Costing R 89000
\end{tabular}

Place a cross over the dot that best represents your preference. 
6. When buying tyres, which of the following proposals would you prefer?

\begin{tabular}{|l|l|l|l|l|l|l|}
\hline $\begin{array}{l}\text { An unbranded tyre offering } 10000 \\
\text { service hours } \\
\text { With a 2 week delivery lead time }\end{array}$ & \multicolumn{3}{|c|}{ Or Michelin tyre } \\
With technical support within 12 hours \\
Costing R 97 000
\end{tabular}

Place a cross over the dot that best represents your preference.

7. When buying tyres, which of the following proposals would you prefer?

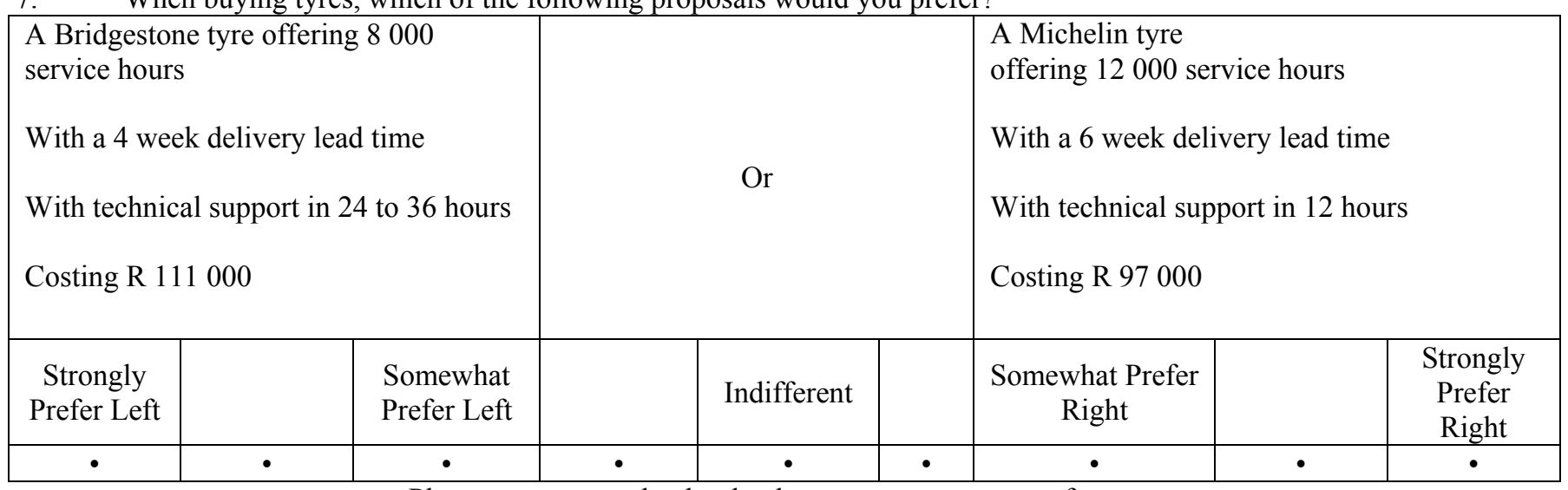

Place a cross over the dot that best represents your preference.

8. When buying tyres, which of the following proposals would you prefer?

\begin{tabular}{|l|l|l|c|c|c|c|}
\hline $\begin{array}{l}\text { A Michelin tyre offering } 8000 \text { service } \\
\text { hours }\end{array}$ & \multicolumn{3}{|c|}{ Or } \\
With a 2 week delivery lead time \\
With technical support in 12 hours
\end{tabular}

Place a cross over the dot that best represents your preference. 
9. When buying tyres, which of the following proposals would you prefer?

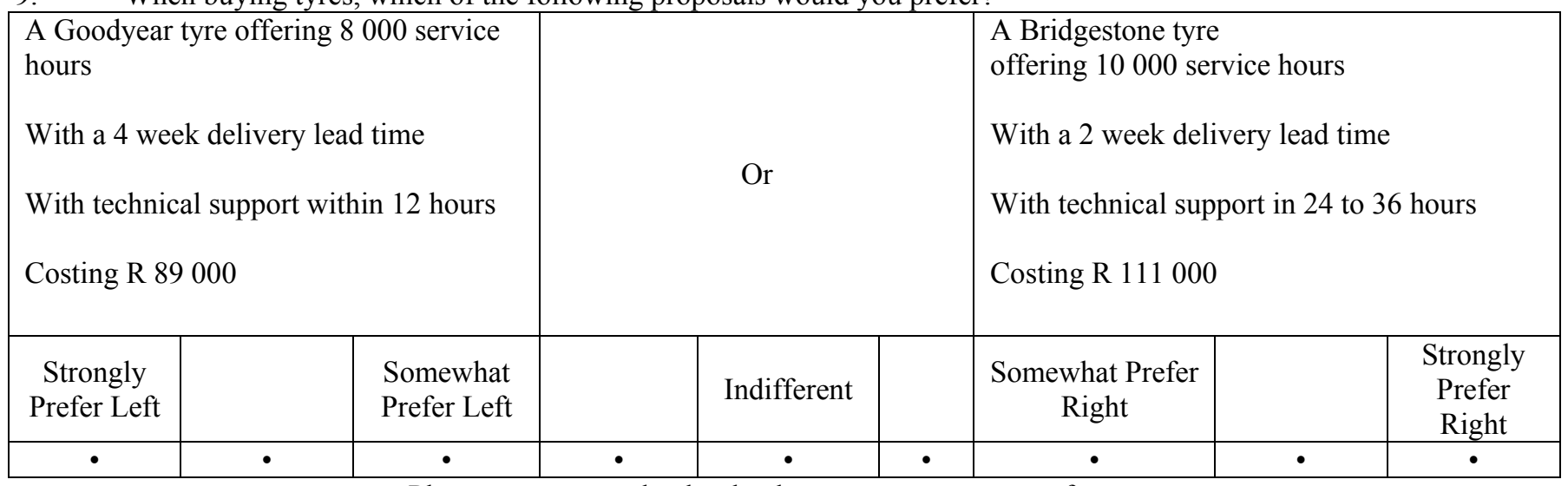

Place a cross over the dot that best represents your preference.

10. When buying tyres, which of the following proposals would you prefer?

\begin{tabular}{|l|c|c|c|c|c|c|}
\hline $\begin{array}{l}\text { A Bridgestone tyre offering } 12000 \\
\text { service hours } \\
\text { With a 4 week delivery lead time }\end{array}$ & \multicolumn{3}{|c|}{ Or } \\
With technical support in 12 to 24 hours \\
Costing R 111000
\end{tabular}

Place a cross over the dot that best represents your preference.

11. When buying tyres, which of the following proposals would you prefer?

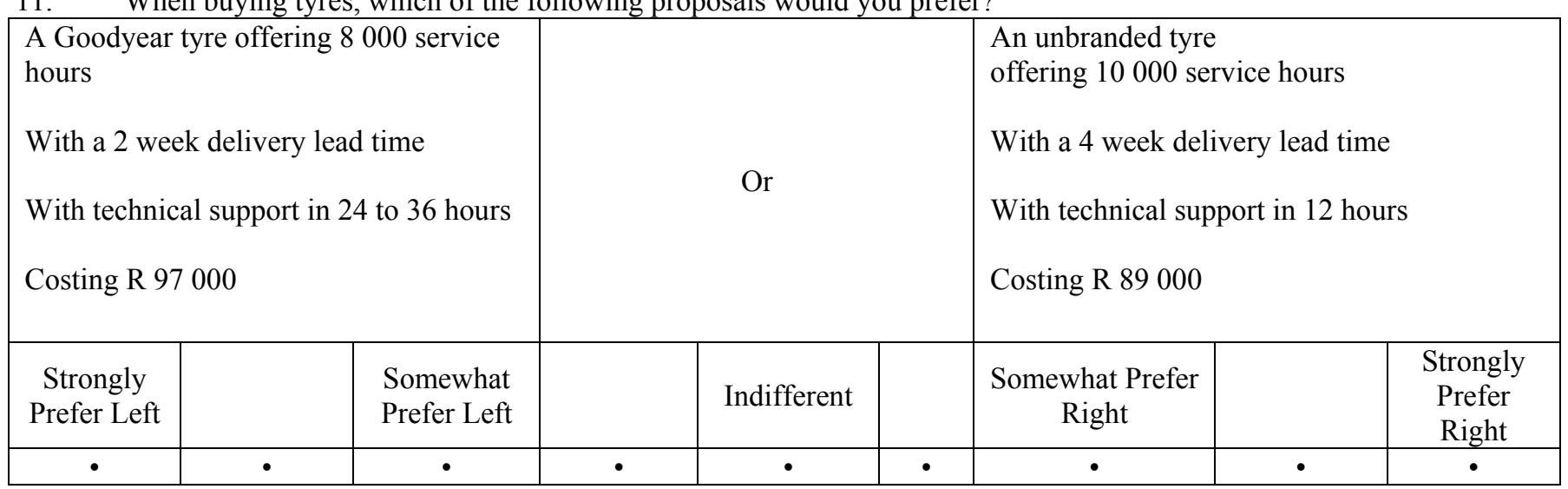

Place a cross over the dot that best represents your preference. 
12. When buying tyres, which of the following proposals would you prefer?

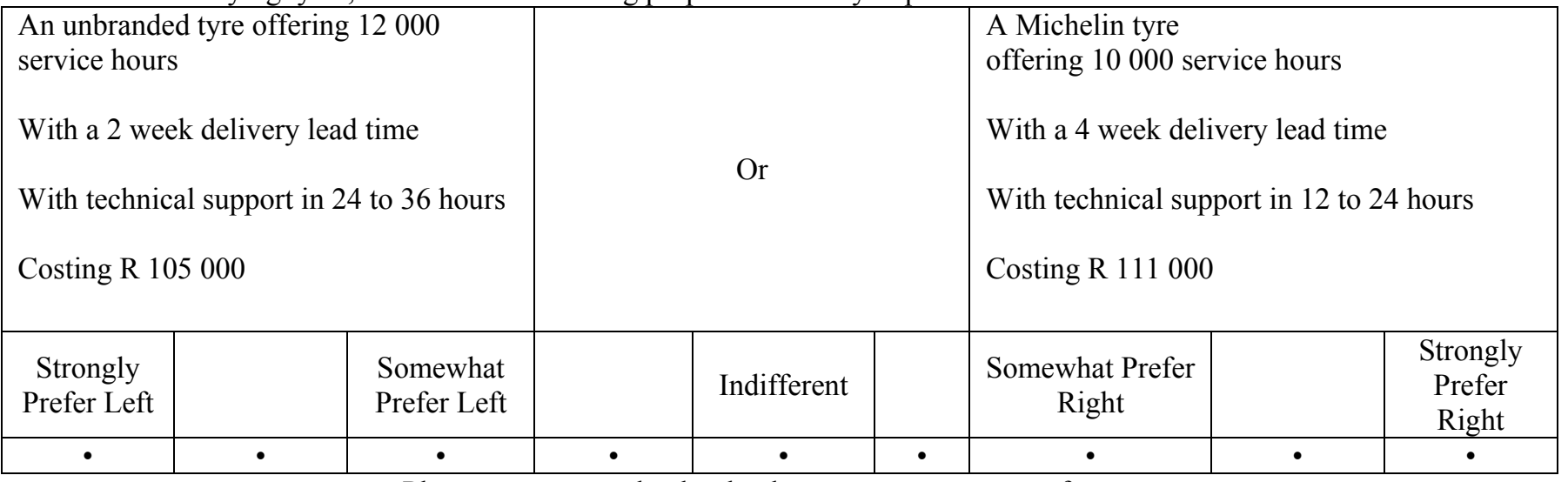

Place a cross over the dot that best represents your preference.

13. When buying tyres, which of the following proposals would you prefer?

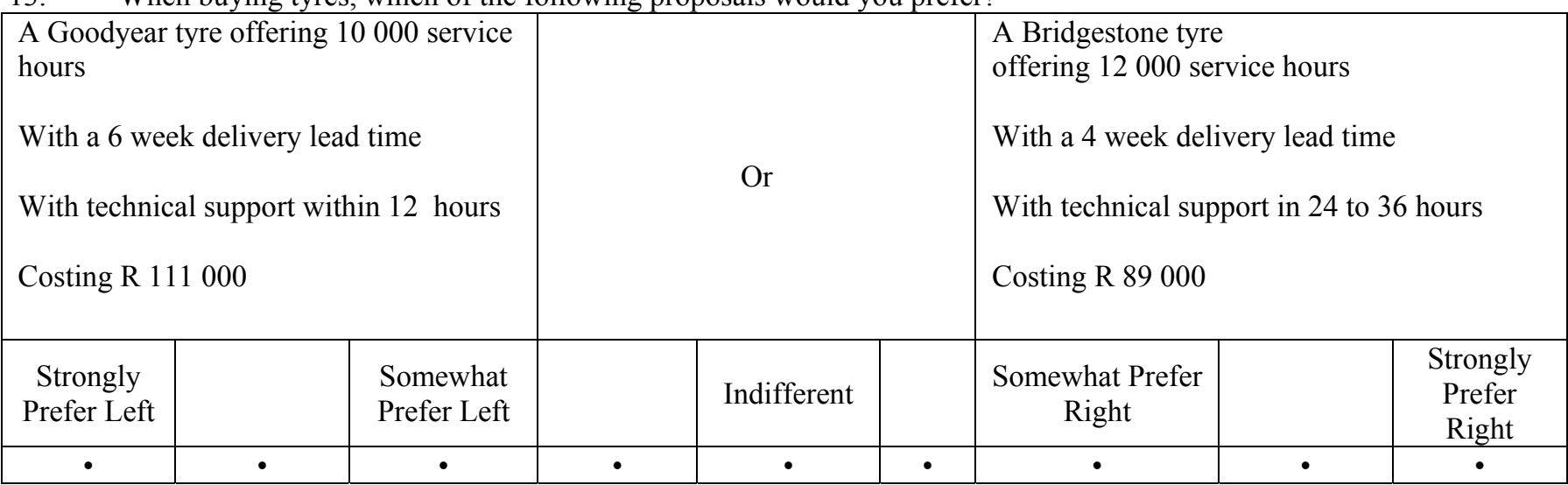

Place a cross over the dot that best represents your preference.

14. When buying tyres, which of the following proposals would you prefer?

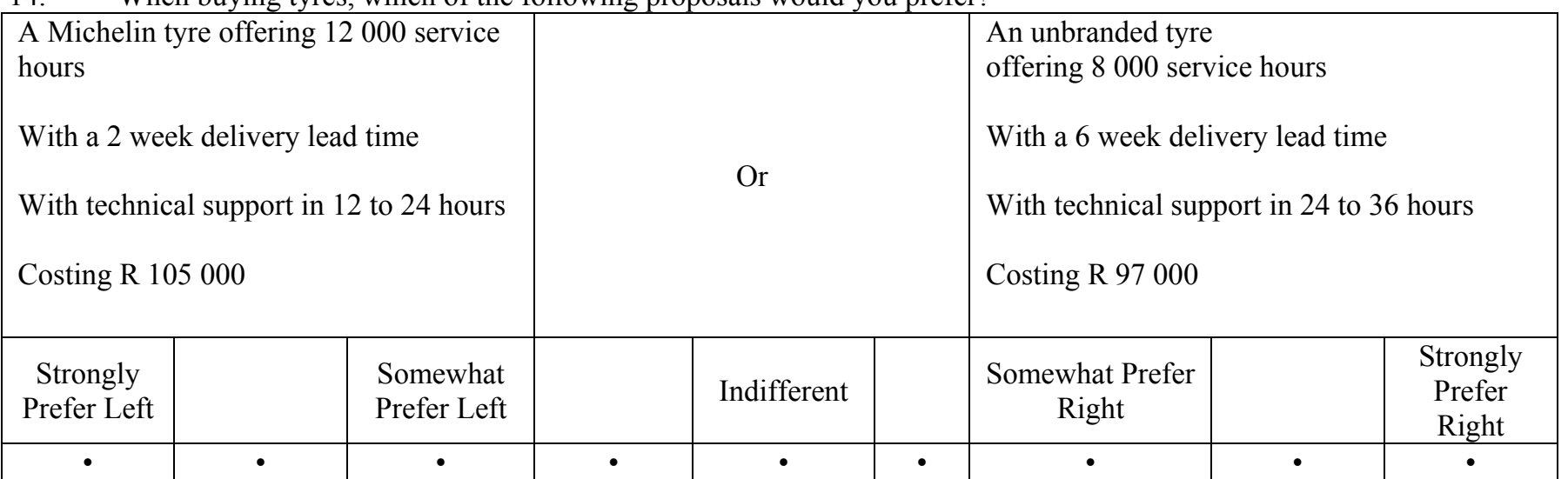

Place a cross over the dot that best represents your preference. 
15. When buying tyres, which of the following proposals would you prefer?

\begin{tabular}{|l|l|l|c|c|c|c|}
\hline $\begin{array}{l}\text { A Bridgestone tyre offering } 8000 \\
\text { service hours } \\
\text { With a } 6 \text { week delivery lead time }\end{array}$ & \multicolumn{3}{|c|}{ Or } \\
With technical support within 12 hours \\
Costing R 105000
\end{tabular}

Place a cross over the dot that best represents your preference. 